\title{
蝸牛空膜の透過性と経蝸牛空膜聴器毒性の実験的研究
}

\author{
東京大学医学部耳鼻咽喉科学教室（主任：野村恭也教授） \\ 原田勇彦
}

\section{EXPERIMENTAL STUDY ON THE PERMEABILITY AND OTOTOXICITY ACROSS THE ROUND WINDOW MEMBRANE}

\author{
TAKEHIKO HARADA, M.D.
}

Department of Otolaryngology, University of Tokyo School of Medicine, Tokyo

Permeability and ototoxicity across the round window membrane was studied in guinea pigs by applying neomycin directly to the round window membrane, and the following results were obtained.

1) Neomycin passed the round window membrane freely, and caused damage to the cochlea.

2) Damage of the cochlea was confined to the organ of Corti. In general, the damage was severest in the basal turn, and was observed more frequently in the outer hair cells.

3) In some cases, the severest damage was observed in the second turn.

4) When neomycin was applied to the round window membrane on both sides, the damage was often quite severe.

5) Damage was observed as early as 4 hours after application of neomycin, and it increased in frequency as the time of application became longer.

6) Damage was compared in normal ears and in ears with experimental otitis media with effusion, and no significant difference was observed. The result appeared to indicate that neomycin passed the round window membrane quite freely regardless of condition of the middle ear mucosa.

7) Analysis of the concentration of neomycin in the perilymph disclosed that neomycin on the round window membrane penetrated into the perilymph quickly, and that its concentration in the perilymph became extremely high, reaching a peak after 2 hours, and then decreased gradually.

8) No consistent relationship was observed between the concentration of neomycin in the perilymph and the presence or absence of the damage at each time interval of neomycin application.

9) Results of this study suggested probable existence of individual variations among guinea pigs.

Key words : 蝸牛空膜, 透過性, 聴器毒性, ネオマイシン, 外リンパ

A $89-0559-23550$

\section{I 緒 言}

ある種の薬片か聴器毒として作用し聴覚前庭障害を おこすことは，すでに 19 世紀後半より知られていた。 この薬剂の聴器毒性が臨床的に重要視されるようにな つたのはストレプトマイシンの出現による. 以来, ア ミ八配梼体抗生物質はその強力な聴器毒性で臨床医の 注目を浴びるようになった。
こうして現在では聴器毒性抗生物質はその全身投与 に関してはかなり注意深く使用されるようになった が，一方でその局所使用に際しての聴器毒性が問題に されるようになった ${ }^{11}$. たとえば聴器毒性抗生物質を 含有する点耳薬の局所使用により生じた難聴は点耳薬 性難聴として知られている22.この場合に薬剤が中耳 から内耳に到達する経路としてはいくつかの可能性が 
考えられるが，このうち蝸牛空膜を透過する経路がも っとも重要視されている3).

他方, 中耳炎に合併して種々の程度の感音難聴や内 耳障害がみられることがある4．また，側頭骨標本の検 索で中耳炎と内リンパ水腫の合併がみられることも少 なくないら，そしてこれら中耳炎と内耳病変の合併に は螖牛空膜の関与が指摘されるようになった6).

こうして蝸牛㤲膜，とくにその透過性に関する関心 が高まり，最近これに関するいくつかの研究報告がみ られるようになった，今回，著者はネオマイシンを用 いて蛊牛空膜の透過性と経蝸牛空膜聴器毒性に関する 種々の実鈳を行い，いくつかの興味ある結果を得たの でこに報告する．実験は目的の異なる3つの部分よ りなるので, 以下にその各部について順に詳述する。

\section{II ネオマイシンの経蝸牛空膜聴器毒性に関する実験}

1. 目的

ネオマイシンは強力な聴器毒性でよく知られたアミ 八配楉体抗生物質で，とくに螖牛に対する毒性が強い といわれているク．ネオマイシン含有の点耳薬を局所 使用することにより難聴が生じることもよく知られて (る32/3).

本実験の目的は蝸牛空膜上に留置したネオマイシン による螖牛障害を観察することにより蝸牛空膜のネオ マイシンに対する透過性を検討することにある。

2. 方法

プライエル反射正常のモルモット10匹を用いて実 験を行った。ネンブタールで麻酔したモルモットの耳 後部に皮周切開を置き，耳胞を開放した。蝸牛空膜を 直視下に置き，小さく切ったゼルフォームの小片を蒸 留水にひたしてこれにネオマイシンの粉末 $5 \mathrm{mg}$ を吸 着させ，螖牛空膜上に直接留置した，耳後部創は一時 的に絴合閉鎖した．表 1 に示すように術後種々の日数 を経た上でそれぞれのモルモットを断頭し，耳胞を採 取した。これをただちに $2.5 \%$ グルタルアルデヒドで 固定, $1 \%$ オスミック酸で後固定し, 脱水後エポン 812 に包埋した，標本は螖牛の各回転ごとに分割してここ の断面より $5 \mu \mathrm{m}$ の厚さの切片を作製し，スライドグ ラスにマウントしてトルイジンブルーで染色し, 光学 顕微鏡下に蝸牛を観察した。

対照としては 5 匹のモルモットを用い，このうち】 匹ではそのまま断頭して上記の方法で標本を作製し， 残る 4 匹では螖牛突膜上に生食にひたしたぜルフォー ムの小片を留置し, 術後 1-10日目に断頭して標本を
表 1 ネオマイシンによる経蝸牛空膜聴器毒性 （1）種々の留置期間における聴器毒性発現の有無

\begin{tabular}{c|c|c}
\hline $\begin{array}{c}\text { モルモット } \\
\text { No. }\end{array}$ & $\begin{array}{c}\text { ネオマイシンの } \\
\text { M日期 }\end{array}$ & 牛痛 \\
\hline 1 & 1 日 & - \\
2 & 1 & - \\
3 & 1 & + \\
4 & 7 & + \\
5 & 8 & + \\
6 & 10 & + \\
7 & 10 & + \\
8 & 10 & + \\
9 & 10 & + \\
10 & 11 & - \\
\hline
\end{tabular}

表 2 ネオマイシンによる経螖牛空膜聴器毒性 （2）渗出性中耳炎耳と正常耳に括汀る比較

\begin{tabular}{|c|c|c|}
\hline \multirow{2}{*}{$\begin{array}{c}\text { モルモット } \\
\text { No. }\end{array}$} & \multicolumn{2}{|c|}{ 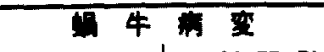 } \\
\hline & 中耳炎佂 & 対盟 \\
\hline 11 & - & + \\
\hline 12 & - & + \\
\hline 13 & - & + \\
\hline 14 & - & + \\
\hline 15 & - & + \\
\hline 16 & - & + \\
\hline 17 & - & + \\
\hline 18 & + & + \\
\hline 19 & + & + \\
\hline 20 & + & + \\
\hline 21 & + & + \\
\hline 22 & + & + \\
\hline 23 & + & + \\
\hline 24 & + & + \\
\hline 25 & + & + \\
\hline 26 & + & - \\
\hline 27 & + & - \\
\hline 28 & + & - \\
\hline 29 & + & - \\
\hline 30 & - & - \\
\hline
\end{tabular}




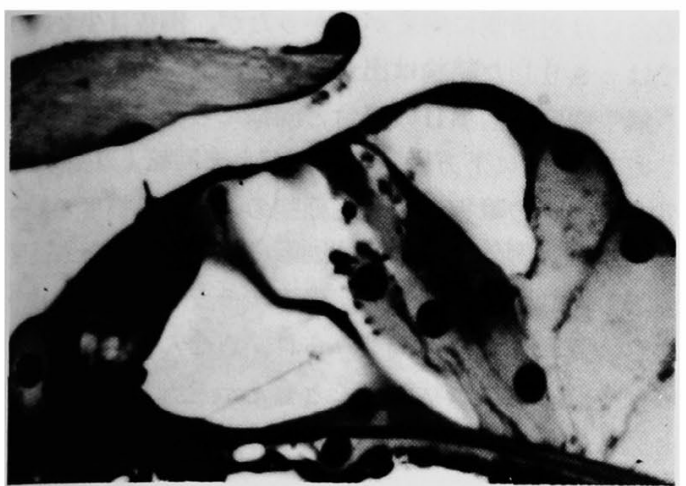

图1 ネオマイシンによる蝸牛病変 (1) モルモットNo.5, 基底回転. ネオマイシン留置 8 日 間. 外有毛細胞に変性, 消失がみられる.内有毛細胞 は残存している.

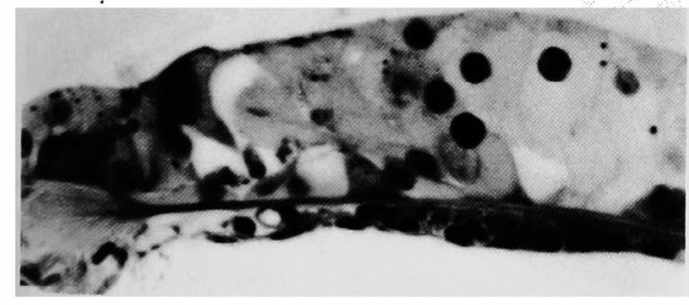

図2 ネオマイシンによる蝸牛病変 (2)

モルモットNo.6, 基底回転。ネオマイシン留置10日 間.らせん器は虚脱して内, 外有毛細胞が変性, 消 失している.

\section{3. 結果}

標本作製方法の関係上,蝸牛のみを観察した. 表 1 に 示すように 10 匹中 7 匹のモルモットで蝸牛に病変が 観察された。この病変はらせん器に限局しており, 内, 外有毛細胞の変性, 消失, あるいはらせん器の虚脱と して観察された. 病変は術後 1 日目のモルモットの一 部ですでに観察されたが, 11 日目のモルモットではみ られなかった。術後 8 日目までにみられた病変は外有 毛細胞の一部が変性, 消失しただけの軽度なものであ つたが(図 1), 10 日目にみられた病変は内，外有毛細 胞の変性, 消失と虚脱をともなう高度なものであった
（図 2). 軽度の病変は基底回転, 第 2 回転のみにみら れ, 高度の病変はさらに上方回転にまでみられたが, その程度は下方回転で高度で上方回転では軽度である かあるいは正常であった。 また内有毛細胞が消失して いる場合は外有毛細胞の消失をともなっていたが，外 有毛細胞が消失している場合は内有毛細胞は残存して いることもあった。

対照としたモルモットでは全例において特別な病変 を認めなかった。

4. 小括

モルモットの蝸牛空膜上にネオマイシンを留置する ことにより蝸牛に病変がみられた。このことよりネオ マイシンは蝸牛空膜を透過して外リンパに移行し, ら せん器に到達してその聴器毒性を発現したと考えられ た.

蝸牛の病変は一般にネオマイシンの留置期間が長い ものが高度であったが例外もあった．初期の病変は外 有毛細胞の変性として始まり, 病変が高度になるにし たがい外有毛細胞の消失, 内有毛細胞の変性, 消失, らせん器全体の虚脱という順に進行すると考えられ た.また同一蝸牛では病変の程度は一般に基底回転に 高度で，上方回転になるにしたがい軽度となった ${ }^{88}$.

\section{III 港出性中耳炎における蝸牛空膜の 透過性に関する実験}

\section{1. 目的}

螖牛空膜の形態的変化はその透過性にかなりの影響 を及ほすと考えられる。これに関連して最近, 渗出性 中耳炎では蝸牛空膜の透過性が高まる可能性が指摘さ れている9.

本実験の目的はモルモットで実験的に作製した渗出 性中耳炎が蝸牛空膜のネオマイシンに対する透過性に どのような変化をもたらすかを検討することにある.

2. 方法

A) 実験的渗出性中耳炎の作製 ネンブタール麻酔下 にモルモットの軟口蓋に切開を入れて一側の耳管咽頭 口を直視下に置き，これにシリコンスポンジの小片を つめ込んで耳管を閉塞した．別のグループのモルモッ トでは一側の耳胞を下方より開放して耳管鼓室口を直 視下に置き，これをエポキシ系樹脂にて閉塞した。術 後 4 日目から 7 日目に耳後部より耳胞を開放すると多 くのモルモットで中耳腔に貯留液を認めた. 一部のモ ルモットで細菌検查を行ったが無菌であることが確認 された。 
表 3 ネオマイシンによる経蝸牛空膜聴器毒性 （3）両側螖牛病変の程度の比較

\begin{tabular}{c|c}
\hline 蛹牛病変の程度 & モルモット数 \\
\hline 中耳炎側 >対 照 侧 & 5 \\
中耳炎側く対 照 側 & 3 \\
\hline
\end{tabular}

表 4 ネオマイシンによる経蝸牛空膜聴器毒性 （4）耳管閉塞の方法により分類した結果

\begin{tabular}{|c|c|c|c|}
\hline \multirow{2}{*}{$\begin{array}{l}\text { 耳管閉寒 } \\
\text { の方法 }\end{array}$} & \multicolumn{2}{|c|}{ 蜡牛病变 } & \multirow{2}{*}{ モルモット数 } \\
\hline & 中耳炎側 & 対 照 侧 & \\
\hline \multirow[t]{3}{*}{ 耳管因頭口 } & & & 6 \\
\hline & - & + & 4 \\
\hline & + & + & 2 \\
\hline \multirow[t]{5}{*}{ 耳管鼓室口 } & & & 14 \\
\hline & 一 & + & 3 \\
\hline & + & + & 6 \\
\hline & $t$ & - & 4 \\
\hline & - & - & 1 \\
\hline
\end{tabular}

B)ネオマイシンの留置 一側は渗出性中耳炎で他側 (対照側) は正常耳のモルモット 20 匹をネンブタール で麻酔し, 耳後部より両側の耳胞を開放して蝸牛空膜 を直視下に置いた。中耳炎側では中耳貯留液を十分に 吸引除去した。 ゼルフォームの小片を蒸留水にひたし てこれに $5 \mathrm{mg}$ のネオマイシン粉末を吸着させ, 両側 の蝸牛空膜上に直接留置した。

C) 標本の作製 翌日に断頭し, 前項IIの 2 で述べた方 法で標本を作製し, 光学顕微鏡下に蝸牛を観察した.

\section{3. 結果}

20 匹のモルモットのうち中耳炎側に蝸牛病変がみ られたのは 12 匹，対照側にみられたのは 15 匹であっ た。両側共にみられたのは 8 匹, 両側共にみられなか ったのは 1 匹であった.これらの結果を表 2 に示すが， 両耳のあいだにはっきりした差はみられなかった。両 側に蝸牛病変がみられた 8 匹でその病変の程度を左右 で比較すると，表 3 に示すようにはっきりした差はみ られなかった。 また病変を耳管閉塞の方法により比較 してみると表 4 のようになる。耳管咽頭口を閉塞した
場合には対照側に病変が多かったが，例数は少ないの ではっきりした結論は出せない.

蝸牛病変は前項 II の場合と同様にらせん器に限局し ており,一般に下方回転の病変が上方回転より高度で, 外有毛細胞の障害が内有毛細胞の障害より高度であっ た. しかし例外として第 2 回転の病変がもっとも高度 である場合もあった．多くのモルモットでは前項IIの 場合よりも高度の病変がみられ，らせん器がほとんど 破壊されたに近い状態のこともあった。 その例を図 3 と図 4 に示す.

\section{4. 小括}

一側には実験的に渗出性中耳炎を作製し他側が正常 耳であるモルモットの両側の蝸牛空膜上にネオマイシ ンを留置し、ネオマイシンによる蝸牛障害を指標とし て蝸牛空膜の透過性を比較, 検討してみると, 両者の あいだに有意の差はみられなかった。
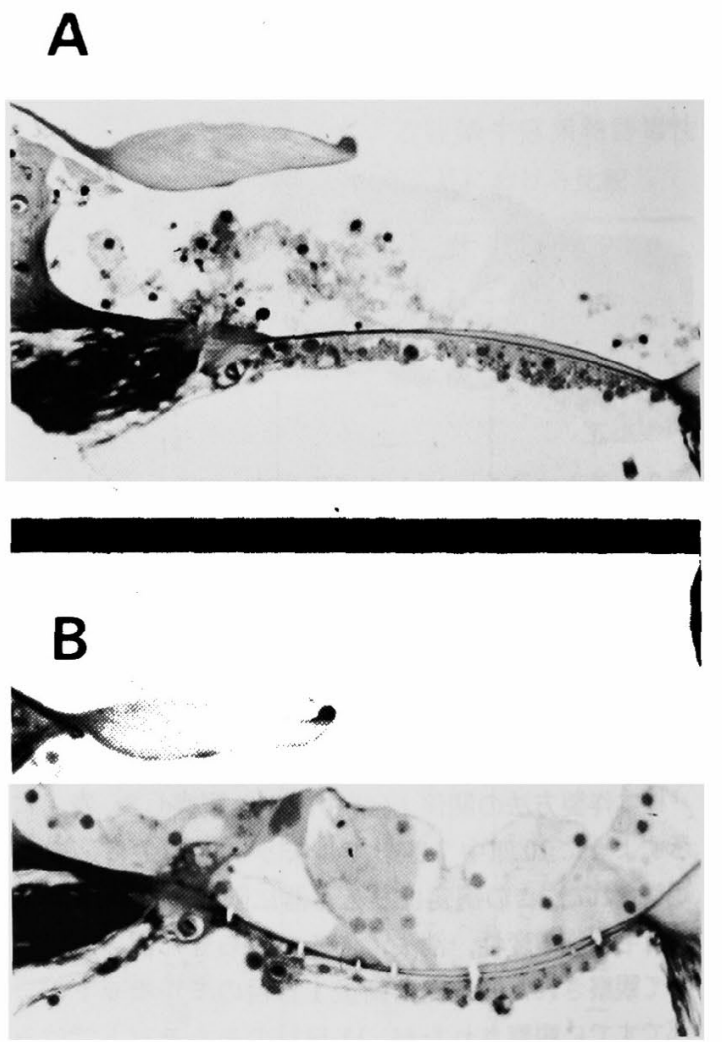

図 3 ネオマイシンによる蝸牛病変 (3) モルモットNo. 18, 基底回転. 両側共に高度の病変が みられるが, 中耳炎側 (A) の病変は対照側 (B)よ り著しい。 
A

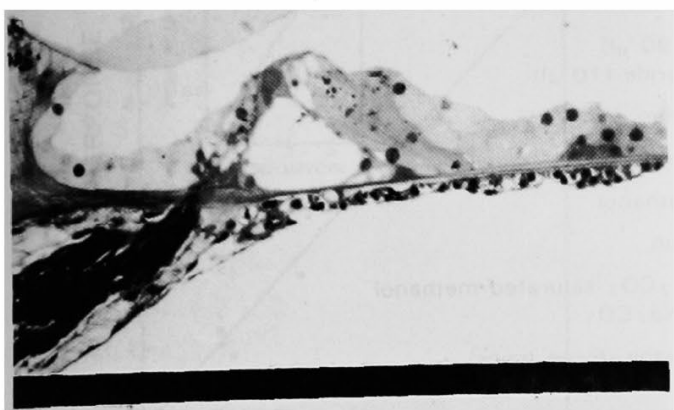

B

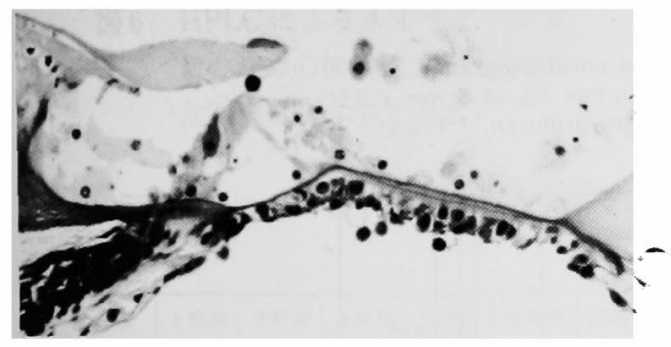

图4 ネオマイシンによる蝸牛病変 (4)

モルモットNo. 23, 基底回転. 両側共に高度の病変が みられるが，対照側（B）の病変が中耳炎側（A）よ り著しい.

以上の結果よりネオマイシンは蝸牛空膜をきわめて 容易に透過し，中耳病変はその透過性にあまり影響は 及涩さないと考えられた。高度の蝸牛病変がみられた 例が多かったのは, 両側の蝸牛空膜上にネオマイシン を留置したためであるのかもしれない. 本実験では同 一の条件下で実験を行ったにもかかわらず病変なしか ら高度病変まで種々の程度の病変がみられた。

\section{IV 外リンパ中のネオマイシンの動態と 経蝸牛空膜聴器毒性に関する実験}

1. 目的

聴器毒性薬劑を全身投与した後の血中，外リンパ中 の薬剤濃度の動態に関しては数多くの研究がなされて (る10)。しかし蝸牛空膜を透過した薬刜の外リンパ中 の動態に関する報告はみあたらない。

本実験の目的は蝸牛空膜を透過したネオマイシンの
外リンパ中濃度を定量してその時間的推移を検討する ことと, ネオマイシンによる経蝸牛空膜聴器毒性の発 現時期, ならびに蝸牛病変と外リンパ中のネオマイシ ン濃度およびネオマイシンの留置時間との関係につい て検討することにある。

2. 方法

A) 高速液体クロマトグラフィー (HPLC) によるネオ マイシンの微量迅速定量法の確立

実験に先立ち，外リンパ中のネオマイシンを定量す る目的で HPLCによるネオマイシンの検出方法を確 立した、ネオマイシンに塩化ベンゾイルを反応させる 一と,ネオマイシンのアミノ基, 水酸基にベンゾイル核 が結合する.こうしてベンゾイル化されたネオマイシ ンは波長 $230 \mathrm{~nm}$ の紫外線に吸収のピークを持つの で, これを HPLCに注入して $230 \mathrm{~nm}$ の波長で検出し た.この反応の操作手順を表 5 に示すが, 詳しい解説 は別項にゆずる11).

B)外リンパ中のネオマイシン濃度の定量

56 匹のモルモットを用いて実験を行った. 耳後部よ り耳胞を開放して蝸牛空膜を直視下に置き, $5 \mathrm{mg}$ のネ オマイシン粉末を蒸留水にひたしたゼルフォームの小 片に吸着させて蝸牛空膜上に留置した。モルモットを 各群 8 匹ずつの 7 群に分け，ネオマイシンの留置時間 を 30 分， 1，2，4，8，16，24 時間の 7 種類として 各群に各留置時間を割り当てた. 各留置時間の経過後 にふたたび耳胞を開放し，ただちにゼルフォームを除 去して中耳を生食にてよく洗浄した。続いて電動ドリ ルにて蝸牛の基底回転鼓室階に小孔をあけ，マイクロ ピペットで $6 \mu 1$ の外リンパを採取した. 外リンパは採 取後に直接凍結乾燥し,この中に含まれるネオマイシ ンを上記の方法で定量した。

\section{C) 蝸牛病変の観察}

ネオマイシンの留置 $4,8,16,14$ 時間後に外リン パを採取したうちの各群 4 匹,計 16 匹のモルモットは ただちに断頭して蝸牛を取り出し，IIの 2 項で述べた 方法で標本を作製して光学顕微鏡下に観察した。

3. 結果

\section{A) HPLCによるネオマイシンの定量}

ネオマイシンと同様にカナマイシン, ストレプトマ イシン, ジヒドロストレプトマイシンを反応させて得 られた HPLCのクロマトブラムを図 5 に示す.いずれ も多峰性のピークを呈し，これら 4 種類の薬剤が HPLC で検出できることがわかる. 既知量の薬剂のク ロマトグラムのピーク面積を計算することにより検量 
表 5 HPLCによるネオマイシン微量定量のための操作手順

\section{Analytical Procedure}
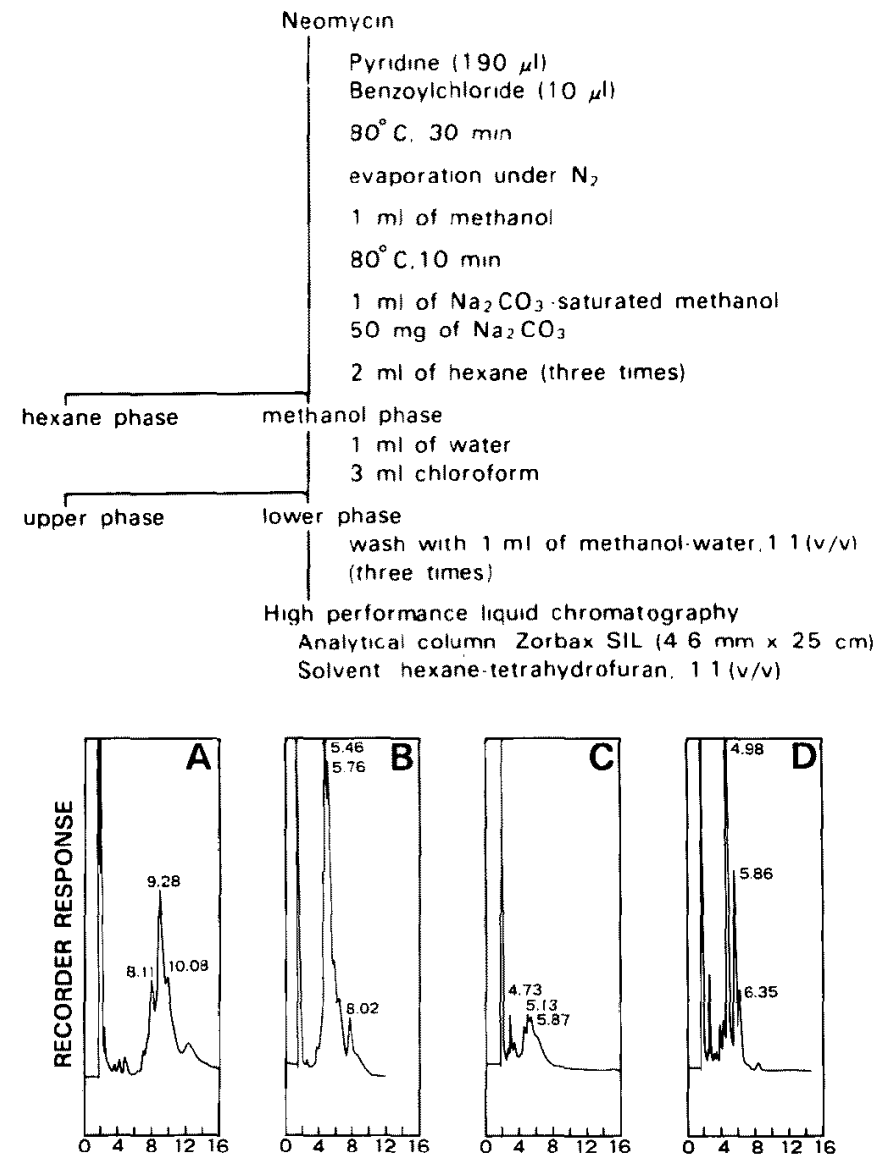

RETENTION TIME (min.)

図 5 各種アミノ配糖体抗生物質の HPLCクロマトグラム
$\mathrm{A}:$ ネマイシン
B：カナマイシン
$\mathrm{C}:$ ストレプトマイシン

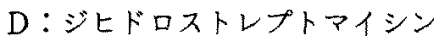

線が作製できる.図6にネオマイシンの検量線を示す。 外リンパ中のネオマイシン濃度はクロマトグラムのピ 一ク面積よりこの検量線を用いて算出される。この方 法によるネオマイシンの検出限界值は実測上 $180 \mathrm{ng}$ で，採取した $6 \mu 1$ の外リンバ中のネオマイシン濃度の 測定限界は $30 \mathrm{ng} / \mu 1$ であった.これはバイオアッセイ やラジオイムノアッセイなどの鋭敏な方法と比較する とかなり低ら感度であるが，比較的簡単な方法で迅速
に行うことができ，常に安定した結果が得られる点は 長所であった。

B)外リンパ中のネオマイシン濃度 表6に56匹のモ ルモットで定量したネオマイシンの外リンパ中㳻度を 示す. 30 分の留置ですでに外リンパ中にはきわめて高 濃度のネオマイシンが検出され，最高值は 2 時間の留 置後にみられた。しかしその後の濃度は徐々に低下し ていき, 24 時間の留置後では全例が湘定限界以下の濃 


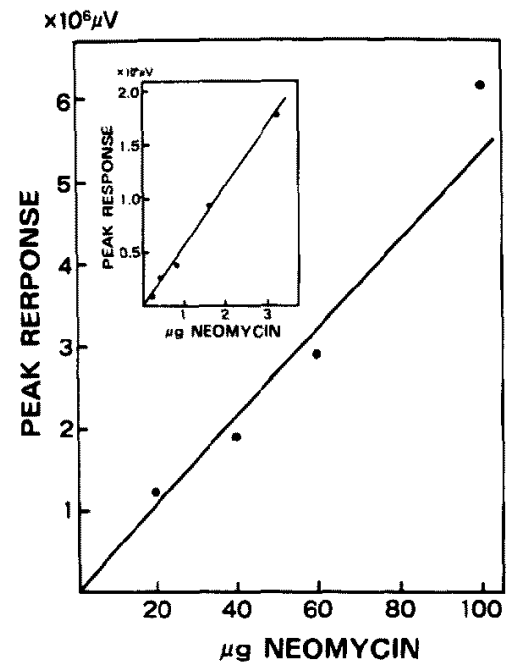

図6 HPLCによるネオマイシン定 量のための検量線（挿入図では 注入濃度が 5 倍でるる

表 6 各留置時間における外リンパ中のネオマイ シン濃度

\begin{tabular}{|c|c|c|c|c|c|c|c|}
\hline 明间 & 30 分 & 1 時成 & 2 基成 & 4 時间 & 8 時間 & 16 時間 & 24時間 \\
\hline \multirow{8}{*}{ 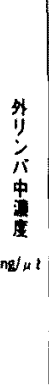 } & 30.7 & 40.3 & 161 & 51.0 & 32.7 & $<30$ & $<30$ \\
\hline & 33.7 & 53.0 & 188 & 77.3 & 37.3 & $<30$ & $<30$ \\
\hline & 36.7 & 62.7 & 205 & 223 & 64.7 & $<30$ & $<\mathbf{3 0}$ \\
\hline & 52.3 & 71.7 & 209 & 227 & 71.0 & $<30$ & $<30$ \\
\hline & 56.3 & 79.3 & 213 & 228 & 167 & 30.0 & $<30$ \\
\hline & 60.7 & 84.7 & 234 & 241 & 198 & 33.7 & $<30$ \\
\hline & 34.7 & 185 & 241 & 247 & 217 & 34.7 & $<30$ \\
\hline & 103 & 206 & 292 & 260 & 261 & 128 & $<30$ \\
\hline
\end{tabular}

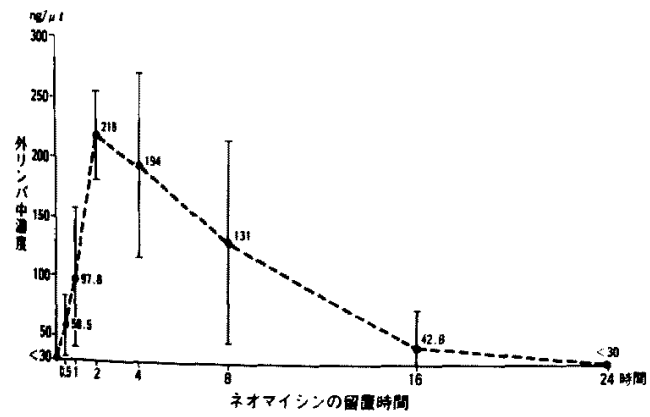

图7 外リンパ中ネオマイシン濃度の各留置時間 における平均值と標準偏差
度であった，図７は各時間での平均值と標準偏差をグ ラフにしたものである. 留置 2 時間まてはネオマイシ ン濃度は急速に上昇してきわめて高濃度となるが，そ の後は 24 時間までのあいだに徐々に低下していく.図 7 から全体的傾向はよくわかるものの，個々の結果に はかなりのばらつきがみられた。

C)螖牛病変と外りンパ中のネオマイシン濃度 16 匹 のモルモットで䗁牛を観察した結果を表 7 に示す。 たそれぞれのネオマイシンの留置時間でそれぞれの外 リンパ中のネオマイシン浪度の位置に蛤牛病変の有無 をプロットすると図 80 ようになった。4 時間のネオ マイシン留置ですでに病変がみられ，留置時間が長く なると病変のおきる割合は增大した。ししかし各留置時 間でみると病変の有無と外リンパ中のネオマイシン濃 度とのあいだに関連はみられなかった。

蛤牛病変は前項 II，IIIの場合と同様にらせん器に限 局していたが，おいてみられたような高度の病変 はみられなかった，外有毛細胞が完全に消失していた

表 7 ホオマイシンの各留置時間に扔ける蛤牛病 変の有無

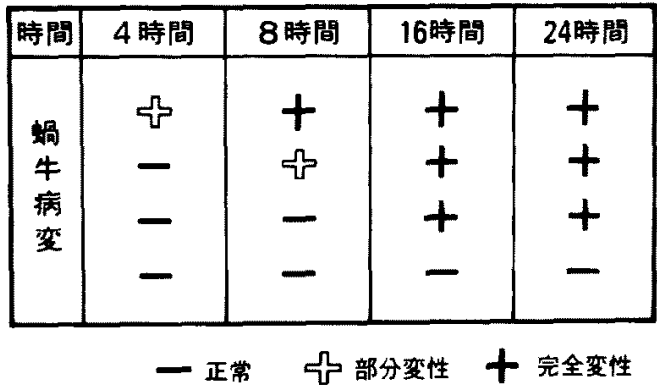

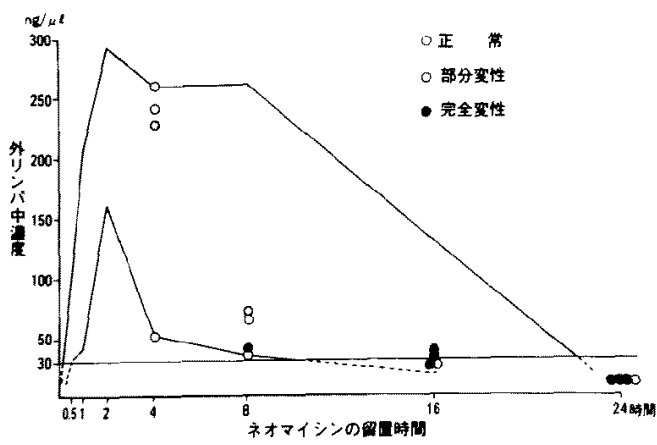

図 8 各留置時間における螖牛病変の有無とその ときの外リンパ中ネオマイシン濃度との関 係 

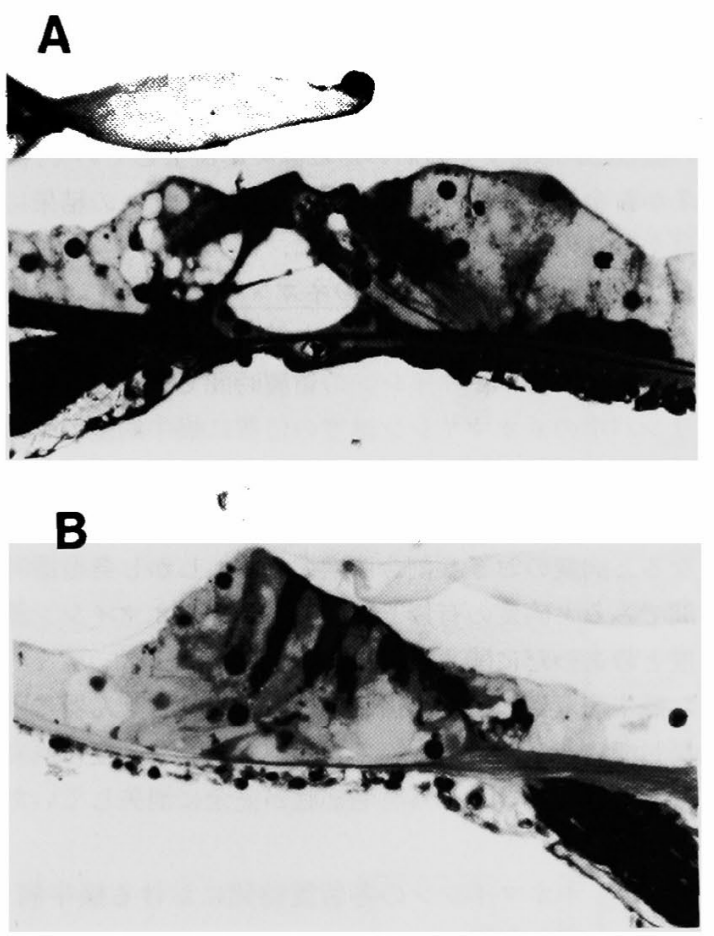

図9ネオマイシンによる蝸牛病変 $(5)$

蝸牛病変の分類例

$\mathrm{A}$ ：完全変性としたもの. 外有毛細胞は消失 しているが、しているが，内有毛細胞は残存し ていることもある(基底回転)。

B：部分変性としたもの. 外有毛細胞が不完 全に変性, 消失している(第 2 回転).

場合は内有毛細胞が残存していても完全変性と分類し たが，これ㹥基底部の病変がもっとも高度で上方回転 は軽度であった，部分変性としたものは外有毛細胞が 不完全に変性, 消失していた場合で，この場合は第 2 回転の病変がもっとも高度であった．図 9 に蝸牛病変 の完全変性と部分変性の例を示す.

\section{4. 小括}

モルモットの蝸牛空膜を透過したネオマイシンの外 リンパ中濃度を HPLCにより定量した結果, 蝸牛空膜 上のネオマイシンは短時間のうちに外リンパに移行し てきわめて高濃度となり, その後は徐々に減少するこ とがわかった。このことよりネオマイシンはきわめて 容易に蝸牛空膜を透過することが推測された。

またネオマイシンによる経蝸牛空膜聴器毒性は短時 間で発現しうることがわかった。これは蝸牛空膜を透
過したネオマイシンの外リンパ中濃度が非常に高くな ることと関係していると考えられる. しかしながらネ オマイシンの留置時間, 外リンパ中のネオマイシン髷 度と蝸牛病変の有無とのあいだに一定の関係はみられ なかった。

\section{V 考察 \\ 1. 経蝸牛空膜聴器毒性について}

局所に点耳した聴器毒性薬剤が内耳に到達する経路 としては蝸牛空, 前庭空, microfissure, 顔面神経, 骨 迷路の血管などが考えられるが，このうちもっとも重 要なのが蝸牛空膜を透過して内耳に到達する経路であ ろう2)31.こうして生じる点耳薬性難聴のヒトにおける 側頭骨標本検索の報告はみられないが，動物実験では 中耳に聴器毒性薬剂を注入した後に内耳を組織学的に 検索した報告がいくつがある. Riskaer et al ${ }^{12)}$ はモル モットの中耳にネオマイシンを注入した実験で聴力に 変化がなかったとして組織学的検索は行わなかった。 Mittelman"1) はネオマイシンを蝸牛空膜に 1 回作用さ せた実験で組織学的に内耳に変化を認めなかった。こ れに対して Kohonen and Tarkkanen ${ }^{13)}$, Brummett et $\mathrm{al}^{14)}$, 中井ら ${ }^{15)}$, Ginsberg et $\mathrm{al}^{16)}$, Wright and Meyerhoff $^{17)}$ はネオマイシンなどの聴器毒性薬剤を 鼓室内に注入することにより引きおこされた内耳病変 を観察している.これらの病変の程度や分布のパター ンについては報告によりかなりの差がみられ，著者の 実験結果とも多少異なるものである. 中井ら ${ }^{15)}$ は動物 差が大であることを強調しているが, 実験動物の差や 実験条件の差が結果に大きく影響していると考えられ る.

著者の結果では一般に病変はらせん器に限局してお り基底回転に高度で上方回転になるにしたがって軽度 となったが，一部では第 2 回転の病変がもつとも高度 である例がみられた、これは蝸牛病変に 3 つのパター ンを認めた Kohonen and Tarkkanen ${ }^{13)}$ の実験結果に 比較的近いものと考えられよう。また一般に外有毛細 胞の障害が内有毛細胞の障害よりも高度であった。こ

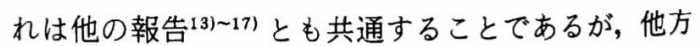
Lindsay et $\mathrm{al}^{18)}$ が報告したネオマイシンの全身投与 により襲となったヒト側頭骨組織標本でみられた内有 毛細胞の障害を主とする所見とは大きく対比されるも のである.ここでも種属差, 投与方法の差が大きく関 係しているものと思われる. Wright and Meyerhoff ${ }^{171}$ はらせん器の障害に加えて血管条にも高度な障害がお 
こることを報告しているが，本実験では病変は高度で あってもらせん器に限局していた。

従来の研究報告をみると鼓室内に聴器毒性薬剂を注 入する方法が多かったが，本実験ではネオマイシンを 蚼牛突膜のみに作用させるためにゼルフォームの小片 を用いた。これにより微量のネオマイシンが定量化さ れて蜗牛空膜上に直接留置されることとなり，鼓室内 注入法と比較すると経蜡牛空膜聴器毒性が上り笽密に 模討でると考えられる。この留置方法は他の報告で はみられない。

経蛤牛空膜聴器毒性の発現時期については本研究で もっとも早くみられたのがネオマイシンを 4 時間留置 した後であり，それより早い時期については検索して いない，他の報告ばー17)ではネオマイシンの鼓室内注 入は数回にわたり繰り返されたり，1回注入の場合は 数日後に内耳を観察しているので，発現時期について は不明である。これに対してクロラムフェニコールを 用いた実験では，Proud et al'19は薬剤を 30 分間作用 させて 3 時間後に蝸牛病変を認めている。本研究より

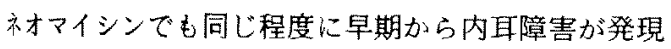
す万可能性が示唆されたそしてその内耳障害は Brummett et $\mathrm{al}{ }^{14)}$ 指摘しているように，ネオマイシ ンの留置時間が長くなるほど高度となっていくと考え bれた.

II, IV項の実験でみられた䖮牛病変と比較するとIII 項の奏験でみられた蛤牛病変には高度なものが多かつ た。これにはらせん器が破壊されたに近いものも含ま れていた，単に実験動物の数が少ないためにこのよう な結果が出たとも考えられるが，それ以外に何か理由 があるようにも思われる，III項とII，IV項の実験の違 いは両側の蝸牛空膜上にネオマイシンを留置したこと でる. Schreiner ${ }^{20)}$ は左右の外りンパ間でイオンの 交換がさかんであることを証明しているが，こうした ことが両側のネオマイシン留置では一側留置の場合と 比皎して両側ともに蝸牛病変を高度なものとしている のかしれない.

本研究ではすべて同一のテクニックで奏験を行った にもかかからず, 結果は病変のまったくみられなかっ たものから高度病変のものまでさまざまであった。こ うした病変出現の不確定さは Kohonen and Tarkkanen'”) の報告でもみられるところであるが,こ れには本研究で用いた方法論に起因する要素のみなら 才゙動物の個体差が関係しているのではないかと思われ る.これに関しては後でふたたび考察を加える。
2. 螖牛突膜の透過性について

前述のように経蝸牛突膜聴器性の発現には蛤牛空 膜の透過性が重要であるが，蝸牛空膜は種々の物質に 対して透過性を有すると考えら机る，現在までにナト リウム211，ヨード22)などのイオンやアミノ配糖体を含 めた抗生物質 23) 25)などの比較的分子量の小さい物質 のみならず,トロトラスト ${ }^{26)}$, horseradish peroxidase $(\mathrm{HRP})^{27128)}$,アルプミン 291301, 外毒素31321 などの高分 子量の物質にいたるまで種々の物質に対する透過性を 証明した報告がなされている。これに対して Galle and Siegel ${ }^{33)}$ はナトリウムは蝸牛空膜を透過しないと 報告しており，中井と金子光) はフェリチンなどの追跡 子を用いた実験で中耳側より内耳側への侵入は困難で あるとしている。

このように蝸午空膜の透過性に関して一部では相反 する結果となってはいるが，実際にはかなり多種類の 物質に刘して透過性を有すると考えてよいであるう。 ネオマイシンに関しては Smith and Myers ${ }^{24}$ が䖮牛 空膜に作用させたネオマイシンを radioenzyme法を 用いて外りンパ中で定量し蝸牛笖膜の透過性を証明し ている。

本研究では蝸牛空膜上に声接留置したネオマイシン による蝸牛障害を観察し，また外りンパ中に移行した ネオマイシンをHPLCで定量した。これにより蛸牛空 膜のネオマイシンに対する透過性は直接的に証明され たといえよう。しかしながらネオマイシンがどのよう にして蛸牛空膜を透過するのかに関してはいまだ开究 がなされていない. HRPに関してはTanaka and Motomura ${ }^{27)}$ が蛤牛空膜上の HRP は細胞吞食作用に よりただちに上皮細胞内にとりこま㧈て䋸牛空膜を透 過することを観察している。ネオマイシンは分子量 908.87 という小さな物質であるのでもつと容易に螖 牛空膜を透過するのではないかと考えられるが，その 過程は不明である。

蝸牛空膜の透過性は中耳粘膜が病的状態の場合には 增大するものと考えられる。現在のところ渗出性中耳 炎29) 311，イオントフォレーゼ22)，パントカインの作 用 ${ }^{26)}$ な゙で螖牛空膜の透過性が高まるとの㬰験結果 が報告されている。このうち滲出性中耳炎の場合は嶇 床的意義も大きく重要な問題となるであろう。本研究 でも実験的に缷出性中耳炎を作製して蛸牛空膜の透過 性の変化を検討した。実験動物数が少ない時点では中 耳炎側に病変が少なく対照側では全例で病変みられた のでこれに対して考察を行ったこともある(3)ー37).し 
かし実験動物数を増やすと両耳のあいだに有意の差は みられなくなった。これはネオマイシンが中耳病変が なくとも正常の状態ですでに非常に容易に蝸牛空膜を 透過することを意味すると考えられよう，中耳病変が 蝸牛空膜の透過性に与える影響をみるには他の報 告291ー31)におけるようにもつと高分子量の物質を用い た方がよかったのかもしれない.

3. 外リンパ中のネオマイシン動態について

アミノ配糖体抗生物質の聴器毒性に関連して, これ らの抗生物質の外リンパ中における動態に関しては数 多くの研究がなされている。現在のところストレプト マイシン38) 42), ジ七ドロストレプトマイシン41), カナ マイシン38(41431 -47), ゲンタマイシン10148499, ネオマイ シン ${ }^{38)(1)}$, トブラマイシン ${ }^{48)}, ア ミ カ シ ン{ }^{48)}$, ネチルマ イシン ${ }^{49)}$, ジベカシン50), リボスタマイシン ${ }^{511}$ に関す る報告がみられる、これらの報告ではアミノ配糖体抗 生物質を筋注，皮下注古るいは腹腔内投与した後の外 リンパ中と血中の動態の比較を行っている。一般に血 中の薬剮濃度は外リンパ中の濃度よりも早くピークに 達してその濃度もずっと高值であるが, 外リンパから の排泄は血中からの排泄に比べるとずっと遅い。しか しながらその詳細なデータを検討すると矛盾するとま ではいかないものの報告によりかなりの違いがみられ る.

これに対して螖牛空膜を透過して外りンパに移行し た楽剤の動態に関しての報告は今のところみあたらな い. 蝸牛空膜を透過した薬郕の外リンパ中での直接定

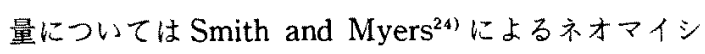
ンとゲンタマイシンの報告, Okuno and Nomura $\mathrm{a}^{25)}$ に よるセフメタゾールの報告があるが，いずれも外リン パ中に拉ける薬凨動態についての検討はなされていな い. 本研究ではこの点についての検討を行った結果, 個々の測定值にはかなりのばらつきをみるものの平均 值をとるとはつきりした一定の傾向を認めることがで きた。これによると外リンパ中のネオマイシン濃度は 急速に上昇し 2 時間でピークとなり, 以後は徐々に減 少した。このパターンは前述の全身投与後の動態と比 較するとピークに達する時間がやや早く、さらにこの ピーク濃度は非常に高値であった。これは䗁牛空膜上 に留置したネオマイシンが微量であることを考慮する と一層際立ったものとなり，ネオマイシンが蝸牛空膜 をきわめて容易に透過することを意味する所見と考え られよう。

経蝸牛空膜聴器毒性の発現にはネオマイシンの留置
時間と外リンパ中の濃度が重要な要素になると考えら れるが, 蝸牛病変の有無と外リンパ中のネオマイシン 濃度とのあいだに一定の関係はみられなかった、これ は結局本研究ではそれぞれの留置時間における外リン パ中の濃度をみたのみであるからで, 聴器毒性の発現 には各実験動物において外リンパ中のネオマイシン濃 度がどのような経過をたどって推移したかが問題とな ってくるのであろう。ささには外リンパ中の濃度より も留置時間のほうが畾器毒性の発現にはより重要であ るのかもしれない.

4. 結果のばらつきについて

本研究に抢ける蝸牛病変の有無とその程度, 外リン パ中ネオマイシン濃度の結果にはかなりのばらつきが みられた。この原因としてまず第 1 に本研究で用いた 方法に固有の要因が考文られる。すなわち $5 \mathrm{mg}$ のネ オマイシン粉末をゼルフォームの小片に吸着させて蝸 牛空膜上に一定時間留置する場合に, 蝸牛空膜に直接 作用したネオマイシンの最終的な量と濃度には䞄密に は各動物間でいくらかの違いが生じていると思われ る.これはもちろん結果にある程度の誴差を生じさせ るが，本研究における結果のばらつきの度合いはこの 誤差の推定範囲を越えるものと考えられる。ここに第 2 の要因として動物の個体差が考えられるのである。

本研究に扔いて個体差を生じる要素としては1)螖 牛空膜のネオマイシンに対する透過性の個体差，2）ネ オマイシンの外リンパからの排泄の個体差，3)ネオマ イシンと有毛細胞との親和性の個体差，4)有毛細胞の 易損傷性の個体差などが考えられる. Ohtani et $\mathrm{al}^{132)}$ はカナマイシンを用いたウサギでの実際で動物の個体 差を内耳への薬鼡移行の個体差に求めているが，実際 には以上の1)から4の要素が様々にからみあってい るのではないだろうか。

\section{VI 結 語}

モルモットの螖牛空膜上にネオマイシンを留置して 蛤牛空膜の透過性と経蝸牛空膜聴器毒性に関する種々 の実験を行った結果，以下のような結論を得た。

1）ネオマイシンは蝸牛空膜を容易に透過して内耳に 移行し, 経蛊牛空膜聴器瑇性をひきおこした。

2）蛤牛病変はらせん器に限局しておゔ，一般に基底 回転に高度で上方回転となるにしたがい軽度となっ た。また外有毛細胞の障害が内有毛細胞の障害より高 度であった。

3）例外として第 2 回転の病変がもっも高度である 
場合があった。

4）両側にネオマイシンを留置した場合には非常に高 度の病変がみられることがあった。

5）ネオマイシンによる経螖牛空膜聴器毒性は比較的 短時間て発現した。またネオマイシンの留置時間が長 くなると蚼牛病変のおきる割合が增大した。

6) 実験的に渗出性中耳炎を作製して中耳病変が蝸牛 空膜の透過性に及浬す影響をみると，対照とのあいだ に有意の差はみられなかった。これは中耳粘膜の状態 と関係なくネオマイシンが蛴牛空膜をきわ容易に 透過するためと考光られた。

7) 外リンパ中のネオマイシンの動態を検討すると， 蛄牛空膜上のネオマイシンは短時間で外リンパに移行 してきわめて高濃度となり，その後は徐々に減少した。 8)蛤牛病変の有無とネオマイシンの留置時間，外り ンパ中のネオマイシン濃度とのあいだには一定の関係 はみられなかった。

9）本研究では結果にかなりのばらつきがみられた がこれにはモルモットの個体差が関係していると考 えられた。

\section{参考文献}

1) Mittelman $\mathrm{H}:$ Ototoxicity of "ototopical" antibiotics: Past, present, and future. Tr Am Acad Ophthalmol Otolaryngol $76: 1432-1443,1972$.

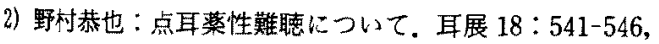
1975.

3）野村恭也：点耳療法による内耳障害について。耳喉 $51: 857-862,1979$.

4) Paparella MM, Oda M, Hiraide F et al : Pathology of sensorineural hearing loss in otitis media. Ann Otol Rhinol Laryngol 81 : 632-647, 1972.

5) Paparella MM, Goycoolea MV, Meyerhoff WL : Endolymphatic hydrops and otitis media. Laryngos. cope $89: 43 \sim 54,1979$.

6) Paparella MM, Goycoolea MV, Meyerhoff ML: Inner ear pathology and otitis media. Ann Otol Rinol Laryngol 89, Suppl 68:249-253, 1980.

7)野村恭也，土田みね子：㯖力障害。中島，秋吉 (編)： 薬物と感覚遥害. ソフトサイエンス社, 東京, 1980,448 -471 頁.

8）野村恭也, 原田勇彦, 川端五十鈴：経蛊牛塋膜聴器毒性 の実験的研究．厚生省特定疾患特発性の感音難聴調查 研究班昭和 55 年度研究報告書, 1981，45-48 頁。

9) Goycoolea MV, Paparella MM, Juhn SK et al:
Otitis media with perforation of the tympanic membrane: A longitudinal exprimental study. Lar. yngoscope $90: 2037-2045,1980$.

10) Tran Ba Huy $P$, Manuel $C$, Meulemans $A$ et al : Pharmacokinetics of gentamicin in perilymph and endolymph of the rat as determined by radioim. munoassay. J Infect Dis $143: 476^{-486}, 1981$.

11) Harada T, Iwamori M, Nagai $Y$ et al : Analysis of aminoglycoside antibiotics as benzoyl derivatives by high-performance liquid chromatography and its application to the quantitation of neomycin in the perilymph. J Chromatogr 337 : 187-193, 1985.

12) Riskaer $N$, Christensen $E$, Petersen $P V$ et al : The ototoxicity of neomycin. Experimental investigations. Acta Otolaryngol 46:137-152, 1956.

13) Kohonen A, Tarkkanen $\mathbf{J}$ : Cochlear damage from ototoxic antibiotics by intratympanic application. Acta Otolaryngol 68:90-97, 1969.

14) Brummett RE, Harris RF, Lindgren JA : Detection of ototoxicity from drugs applied topically to the middle ear space. Laryngoscope 86:1177-1187, 1976.

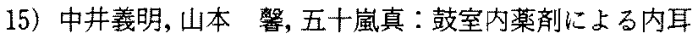
障害. Audiology Japan 17:190-197, 1974.

16) Ginsberg IA, Rudnick MD, Huber PS: Aminog. lycoside ototoxicity following middle ear injection. III. Comparative quantitative analysis. Ann Otol Rhinol Laryngol 89, Suppl $77: 17-24,1980$.

17) Wright CG, Meyerhoff WL: Ototoxicity of otic drops applied to the middle ear in the chinchilla. Am J Otolaryngol $5: 166-176,1984$.

18) Lindsay JR, Proctor LR, Work WP: Histopathologic inner ear changes in deafness due to neomycin in a human. Laryngoscope $70: 382-392$, 1960.

19) Proud GO, Mittelman H, Seiden GD : Ototoxicity of topically applied chloramphenicol. Arch Otolaryngol $87: 580-587,1968$.

20) Schreiner L : Experimentelle Untersuchungen uber die Bildungsstatten und den Stoffaustausch der Perilymphe. Acta Otolaryngol, Suppl 212, 1966.

21) Brady DR, Pearce JP, Juhn SK: Permeability of round window membrane to ${ }^{22} \mathrm{Na}$ or RISA. Arch Otorhinolaryngol $214: 183-184,1976$.

22) Stecker $\mathrm{RH}$, Cody DTR: Iontophoresis of ${ }^{22} \mathrm{Na}$ and ${ }^{13: I}$ into the inner ear. Arch Otolaryngol $83: 213$ 
$-217,1966$.

23) Breuninger $H$, Giebel $W$, Haug $H-P$ : Uber das Eindringen von tympanal appliziertem Tetracyclin in das Innenohr des Meerschweinchens. Arch Otorhinolaryngol $216: 523-524,1977$.

24) Smith BM, Myers MG: The penetration of gentamicin and neomycin into perilymph across the round window membrane. Otolaryngol Head Neck Surg $87: 888-891,1979$.

25) Okuno $T$, Nomura $Y$ : Permeability of the round window membrane. Arch Otorhinolaryngol 240 : 103-106, 1984.

26) Hoft J:Die Permeabilitat und die Beeinflussung der Permeabilitat der Membran des runden Fensters durch Pantocain (Tetracain). Arch Klin Exp Ohr ${ }^{-}$ Nas-Kehlk Heilk 193: 128-137, 1969.

27) Tanaka K, Motomura S : Permeability of the labyrinthine windows in guinea pigs. Arch Otorhinolar. yngol $233: 67-75,1981$.

28) Saijo S, Kimura RS: Distribution of HRP in the inner ear after injection into the middle ear cavity. Acta Otolaryngol $97: 593-610,1984$.

29) Goycoolea MV, Paparella MM, Goldberg B et al : Permeability of the round window membrane in otitis media. Arch Otolaryngol 106:430-433, 1980.

30) Goldberg B, Goycoolea MV, Schlievert PM et al : Passage of albumin from the middle ear to the inner ear in otitis media in the chinchilla. Am J Otolaryngol $2: 210-214,1981$.

31) Goycoolea MV, Paparella MM, Goldberg B et al : Permeability of the middle ear to staphylococcal pyrogenic exotoxin in otitia media. Int $\mathrm{J}$ Pediat Otorhinolaryngol 1: 301-308, 1980.

32) Schachern PA, Paparella MM, Goycoolea MV et al: The round window membrane following application of staphylococcal exotoxin: An electron microscopic study. Laryngoscope 91:2007-2016, 1981.

33) Golle E, Siegel G: The transport of radioactive labelled sodium ions at the round window. Acta Otolaryngol $79: 108-110,1975$.

34）中井義明，金子害：正円空膜一微細構造ならびに透 過性について一。 三王臨床 $68: 223-232,1975$.

35）源田勇彦, 川端五十鈴, 野村恭也：蝸牛空膜の透過性に

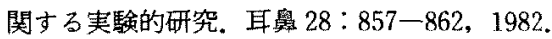

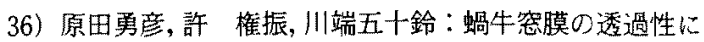

関する赛験的研究一第 2 報一。 Ear Res Jpn 14:208一 $210,1983$.

37）野村恭也, 原田勇彦, 許 権振, 川端五十敛 : 螖牛空膜 の透過性に関する実験的研究（II），厚生省特定疾患急 性高度難聴調查研究班昭和 57 年度研究業績報告書, 1983，67-71 頁.

38) Voldrich L: The kinetics of streptomycin, kanamycin and neomycin in the inner ear. Acta Otolaryngol $60: 243-248,1965$.

39) Vrabec DV, Cody DTR, Ulrich JA : A study of the relative concentrations of antibiotics in the blood, spinal fluid, and perilymph in animals. Ann Otol Rhinol Laryngol $74: 688-705,1965$.

40) Wagner WH, Chou JTY, Ilberg Ch v et al : Untersu. chungen zur Pharmakokinetik von Streptomycin. Arzneim Forsch $21: 2006-2016,1971$.

41) Stupp H, Kupper K, Lagler $F$ et al : Inner ear concentrations and ototoxicity of different antibiotics in local and systemic application. Audiology $12: 350-363,1973$.

42) Ilberg $\mathrm{Ch} v$, Amold $W$, Ritter $\mathrm{R}$ : Ursachen und Beeinflussung der Ototoxizitat des Streptomycins und verwandter Antibiotika. Laryngol Rhinol 53 : 112-120, $197 \overrightarrow{4}$.

43) Watanabe $Y$, Nakajima R, Oda $R$ et al: Experimental study on the transfer of kanamycin to the inner ear fluids. Med J Osaka Univ 21:257-263, 1971.

44) Ohtani I, Mizuno S, Mafune N et al : Experimental study of kanamycin concentration in blood, cerebrospinal fluid and perilymph in rabbits. Fukushima J Med Sci $22: 11-16,1976$.

45) Toyoda $Y$, Tachibana $M$ : Tissue levels of kanamycin in correlation with oto- and nephrotoxicity. Acta Otolaryngol 86: 9-14, 1978.

46) Russell NJ, Fox KE, Brummett RE:Ototoxic effects of the interaction between kanamycin and ethacrynic acid. Acta Otolaryngol $88: 369-381$, 1979.

47) Juhn SK, Rybak LP, Prado S: Nature of bloodlabyrinth barrier in experimental conditions. Ann Otol Rhinol Laryngol $90: 135-141,1981$.

48) Federspil P, Schatzle W, Tiesler E: Pharmacokinetics and ototoxicity of gentamicin, tobramycin, and amikacin. J Infec Dis 134, Suppl: S200-S205, 1976 . 
49) Brummett RE, Fox KE, Brown RT et al : Comparative ototoxic liability of netilmicin and gentamicin. Arch Otolaryngol $104: 579-584,1978$.

50) Ohtani I, Ohtsuki K, Aikawa $T$ et al : Ototoxicity of aminoglycoside antibiotics by rapid intravenous injection. ORL $44: 156-169,1982$.

51) Harpur ES, Gonda I : Analysis of the pharmacokinetics of ribostamycin in serum and perilymph of guinea pigs after single and multiple doses. Brit J Audiol 16:95-99, 1982.

52) Ohtani I, Ohtsuki $K$, Aikawa $T$ et al: Individual variation and mechanism of kanamycin ototoxicity in rabbits. Acta Otolaryngol $94: 413-419,1982$.
稿を終わるにあたり終始御指導いただいた恩師東京大学 医学部聑鼻㸶喉科野村恭也教授，絶えず御助言いただいた 埼玉医科大学総合医療センター耳鼻咽喉科川端五十鈴教 授, HPLCに関して御指導, 御助言いただいた東京大学医 学部第 2 化学永井克孝教授，同岩森正男博士に深謝する。

なお本論文の要旨は厚生省特定疾患特発性の感音難聴調 查研究班昭和 55 年度第 1 回総会, 同 56 年度第 2 回総会, 厚 生省特定疾患急性高度難聴調査研究班昭和 57 年度第 2 回 総会，同 58 年度第 2 回総会，ならびに第 29 回，第 30 回， 第 32 回日本基礎耳科学会において発表した。

(原稿受付 昭和 60.8 . 7 日)

別刷請求先 $=113$ 東京都文京区本郷 7-3-1

東京大学医学部耳鼻咽喉科学教室原田 勇彦 